\title{
Which Markers Play a Role in Diabetic Polyneuropathy and Neuropathic Pain?
}

\section{Diyabetik Polinöropati ve Nöropatik Ağrıda Hangi Belirteçler Rol Oynuyor?}

\section{(D) Mehlika Panpallı Ateş1, (D) Sevgi Ferik², (D Hayat Güven1, (D Selim Selçuk Çomoğlu1}

1University of Health Sciences Turkey, Dışkapı Yıldırım Beyazıt Training and Research Hospital, Clinic of Nurology, Ankara, Turkey

${ }^{2}$ Kahramanmaraş Necip Fazıl City Hospital, Clinic of Neurophysiology, Kahramanmaraş, Turkey

\section{Abstract}

Objective: In diabetes mellitus (DM) patients, in the development of neuropathy and pain, uric acid (UA), C-reactive protein (CRP), $\gamma$-glutamyltransferase (GGT), erythrocyte sedimentation rate (ESR), and fibrinogen increased levels may affect the being of neuropathy by increasing oxidative stress through mechanisms related to inflammation and vascular impairment. In the study, we intended to compare serum UA, GGT, CRP, ESR, and fibrinogen levels in type 2 DM patients, with and without polyneuropathy.

Method: Ninety-six type 2 DM patients and 24 participants were included in the study. Physical examinations, neuropathic pain scales, laboratory tests (UA, GGT, CRP, ESR, and fibrinogen levels), and electroneuromyography were evaluated.

Results: Ninety-six type 2 DM patients and 24 healthy persons were included in the study as the study and control groups. Diabetic polyneuropathy (DPN) patients with neuropathic pain showed that CRP and low-density lipoprotein cholesterol levels were statistically significantly higher. No statistically significant difference was found between the groups in terms of UA, GGT, CRP, and fibrinogen levels.

Conclusion: Increased CRP levels in DPN patients with neuropathic pain may reflect the inflammatory mechanisms involved in the pathogenesis of pain associated with DPN.

Keywords: CRP, diabetes mellitus, diabetic neuropathic pain, diabetic peripheral neuropathy, uric acid

\section{Öz}

Amaç: Diabetes mellitus (DM) hastalarında nöropati ve ağrı gelişiminde ürik asit (UA), C-reaktif protein (CRP), $\gamma$-glutamiltransferaz (GGT), eritrosit sedimantasyon hızı (ESR) ve fibrinojen seviyelerinin artışı, enflamasyon ve vasküler hasara bağı mekanizmalar yoluyla oksidatif stresi artırarak nöropati gelişiminde rol oynayabilir. Bu çalışmada polinöropati olan ve olmayan tip 2 DM'li hastalarda serum UA, GGT, CRP, ESR ve fibrinojen düzeylerini karşılaştırmayı amaçladık.

Yöntem: Çalışmaya toplam 96 tip 2 DM hastası ve 24 kişi (kontrol grubu) dahil edildi. Fizik muayeneler, nöropatik ağrı ölçekleri, laboratuvar testleri (UA, GGT, CRP, ESR ve fibrinojen seviyeleri) ve elektronöromiyografi değerlendirildi.

Bulgular: Doksan altı tip 2 DM hastası ve 24 sağlıklı kişi çalışma ve kontrol grubu olarak çalışmaya alındı. Nöropatik ağrısı olan diyabetik polinöropati (DPN) hastalarında CRP ve düşük yoğunluklu lipoproteinkolesterol düzeylerinin istatistiksel olarak anlamlı derecede yüksek olduğu görüldü. Gruplar arasında UA, GGT, CRP ve fibrinojen düzeyleri açısından istatistiksel olarak anlamlı fark bulunmadı.

Sonuç: Nöropatik ağrılı DPN hastalarında artmış CRP seviyeleri, DPN ile ilişkili ağrı patogenezinde yer alan enflamatuvar mekanizmaları yansıtabilir.

Anahtar kelimeler: CRP, diabetes mellitus, diyabetik nöropatik ağrı, diyabetik periferik nöropati, ürik asit

Address for Correspondence: Mehlika Panpallı Ateş, University of Health Sciences Turkey, Dışkapı Yıldııım Beyazıt Training and Research Hospital, Clinic of Nurology, Ankara, Turkey

E-mail: muefhulkika@gmail.com ORCID: orcid.org/0000-0002-9744-9255 Received: 24.05.2021 Accepted: 15.08.2021

Cite this article as: Panpallı Ateş M, Ferik S, Güven H, Çomoğlu SS. Which Markers Play a Role in Diabetic Polyneuropathy and Neuropathic Pain? Bagcilar Med Bull 2021;6(3):320-325

${ }^{\circ}$ Copyright 2021 by the Health Sciences University Turkey, Bagcilar Training and Research Hospital Bagcilar Medical Bulletin published by Galenos Publishing House. 


\section{Introduction}

Diabetic polyneuropathy (DPN) is one of the furthest widespread long-term complications of type 2 diabetes mellitus (DM) that leads to significant disability and mortality among patients (1).

High serum uric acid (UA), $\gamma$-glutamyltransferase (GGT), C-reactive protein (CRP), fibrinogen levels, which are considered to be predictive of atherosclerosis, have also been associated with DPN (2-5).

UA is an effective extracellular radical scavenger and is responsible for the clearance of $60 \%$ of free radicals in human serum, as well as stimulating granulocyte adhesion to the endothelium and the release of peroxide and superoxide free radicals. It has been suggested that normal levels of UA have an antioxidant effect while high levels of UA have a prooxidant effect that increases oxidative stress. In the subsequent steps of the atherosclerosis (when serum UA levels rised to $6 \mathrm{mg} / \mathrm{dL}$ in women and $6.5-7.0 \mathrm{mg} / \mathrm{dL}$ in men), this antioxidant paradoxically becomes prooxidant (6).

GGT activity may act in the formation and progression of atherosclerotic lesions (4). Increased serum GGT activity is a marker that shows increased CRP in patients with coronary artery atherosclerosis and is associated with the severity and complications of this disease $(5,7)$.

CRP is an acute-phase reactant synthesized by hepatocytes, which is used for diagnosis in individuals with infection or inflammation. CRP, an inflammatory marker, has been associated with the presence and progression of carotid atherosclerotic disease. Even, it has been found in atherosclerotic plaques and has been held responsible for plaque vulnerability. Besides, it has been reported that the formation of restenosis is triggered by increasing CRP $(5,7-$ $10)$.

Erythrocyte sedimentation rate (ESR) and CRP are a further inflammatory response marker associated with inflammation and tissue damage (8).

Fibrinogen, a coagulation factor, is also an acute phase reactant. Besides, inflammatory markers such as fibrinogen are related to a poor prognosis of the acute coronary syndrome (11).

In patients with DM, high UA, GGT, CRP, fibrinogen levels can lead to the development of neuropathy by increasing oxidative stress and causing vascular damage. Identifying and modifying indicators that can guess the risk of developing DPN may contribute to the diagnosis and treatment of DPN. Our purpose is to compare the serum UA, GGT, CRP, and fibrinogen levels in the polyneuropathy groups.

\section{Materials and Methods}

Ninety-six type 2 DM patients and 24 healthy participants aged between 18 and 70 years were recorded in the study. Patient histories, physical examinations, and laboratory tests were evaluated, and consequently, patients with additional potential etiologies in polyneuropathies other than DM, including toxic (e.g., alcohol or chemotherapy), genetic or inflammatory etiologies; patients with systemic diseases which may cause PNP (patients with connective tissue disease, chronic liver disease, malignancies, systemic diseases involving thyroid diseases, patients with low serum vitamin B12 levels or receiving vitamin B12 replacement); patients with a history of infection in the last two weeks; and individuals who took drugs that affected plasma UA levels were excluded from the study. Healthy volunteers at similar ages to the patient group, who did not have DM and had normal HbAlC levels and no PNP findings in an ENMG were enrolled in the control group.

The participants were examined with respect to the polyneuropathy protocol by electroneuromyography (ENMG) (Neuropack MEB-9200K, Nihon Kohden Co., Tokyo, Japan). In the right extremities, sensory and motor conductions of the median, ulnar, peroneal, posterior tibial nerves, and bilateral sural nerves were examined using disc electrodes. Diabetic sensorimotor polyneuropathy was diagnosed considering the patients' symptoms and ENMG results. For those subjects, considering the diagnostic criteria, the advised Toronto Expert Panel on diabetic neuropathy was used (12). For each patient, neuropathic symptoms' duration, Douleur Neuropathique en 4 questions scores, neuropathy symptoms score, neuropathy disability score (NDS), Leeds assessment of neuropathic symptoms and signs (LANSS) scale were assessed.

Patient demographic characteristics (gender, age, body mass index (BMI), age of DM onset, duration of disease, and treatments (oral antidiabetic drugs, insulin) were recorded. Also, patients were questioned regarding the history of HT, atherosclerotic heart disease and stroke, peripheral artery disease, smoking, and alcohol use.

The laboratory tests were taken and were investigated for serum UA, GGT, CRP, fibrinogen levels, hemogram, fasting blood glucose, serum HbAlc levels, C peptide, 
serum creatinine, total cholesterol, low-density lipoprotein (LDL), high-density lipoprotein (HDL), triglycerides (TG), liver function tests (LFTs), ESR, ferritin levels, and thyroid function tests. Immunoelectrophoresis and urine tests were performed.

\section{Statistical Analysis}

Statistical analysis was applied using a Statistical Package for Social Sciences (SPSS®) 22.0 for Windows and Mac os x. The Shapiro-Wilk test was used to test the hypothesis of normality. During the assessment of study data, frequency distributions were provided for categorical variables, and descriptive statistics (mean \pm standard deviation) were provided for constant variables. Descriptive statistics were used for continuous variables. The Independent Samples t-test was used to determine whether there was a difference between two independent groups for normally distributed variables. The chi-square test was used to examine the relationship in two independent categorical variables. Categorical variables were summarized as $\mathrm{N}(\%)$, while normally distributed variables were summarized as mean (standard deviation) and continuous variables were summarized as median (minimum-maximum). p-values of less than 0.05 were accepted significant.

\section{Results}

Ninety-six type 2 DM patients (53 female, 43 male) and 24 healthy subjects as the control group (14 female, 10 male; $52.21 \pm 5.16$ ) were included in the study. Depending on the Toronto Expert Panel on diabetic neuropathy, $60.6 \%$ of patients $(n=62)$ were diagnosed with diabetic sensorimotor polyneuropathy (DSPN), 24 patients were diagnosed with confirmed clinical DSPN and 38 patients were diagnosed with probable DSPN (12). The demographic, clinical, and laboratory characteristics of the patient and control groups are shown in Table 1.

A comparison of the control group and patients with and without DPN revealed no statistical significance in terms of UA, GGT, CRP, and fibrinogen levels. HbAlC and ESR were significantly higher in the patient groups with or without DPN compared to the control group $(\mathrm{p}=0.000, \mathrm{p}=0.001$, respectively) (Table 1).

Table 1. The demographic and disease characteristics of the subjects

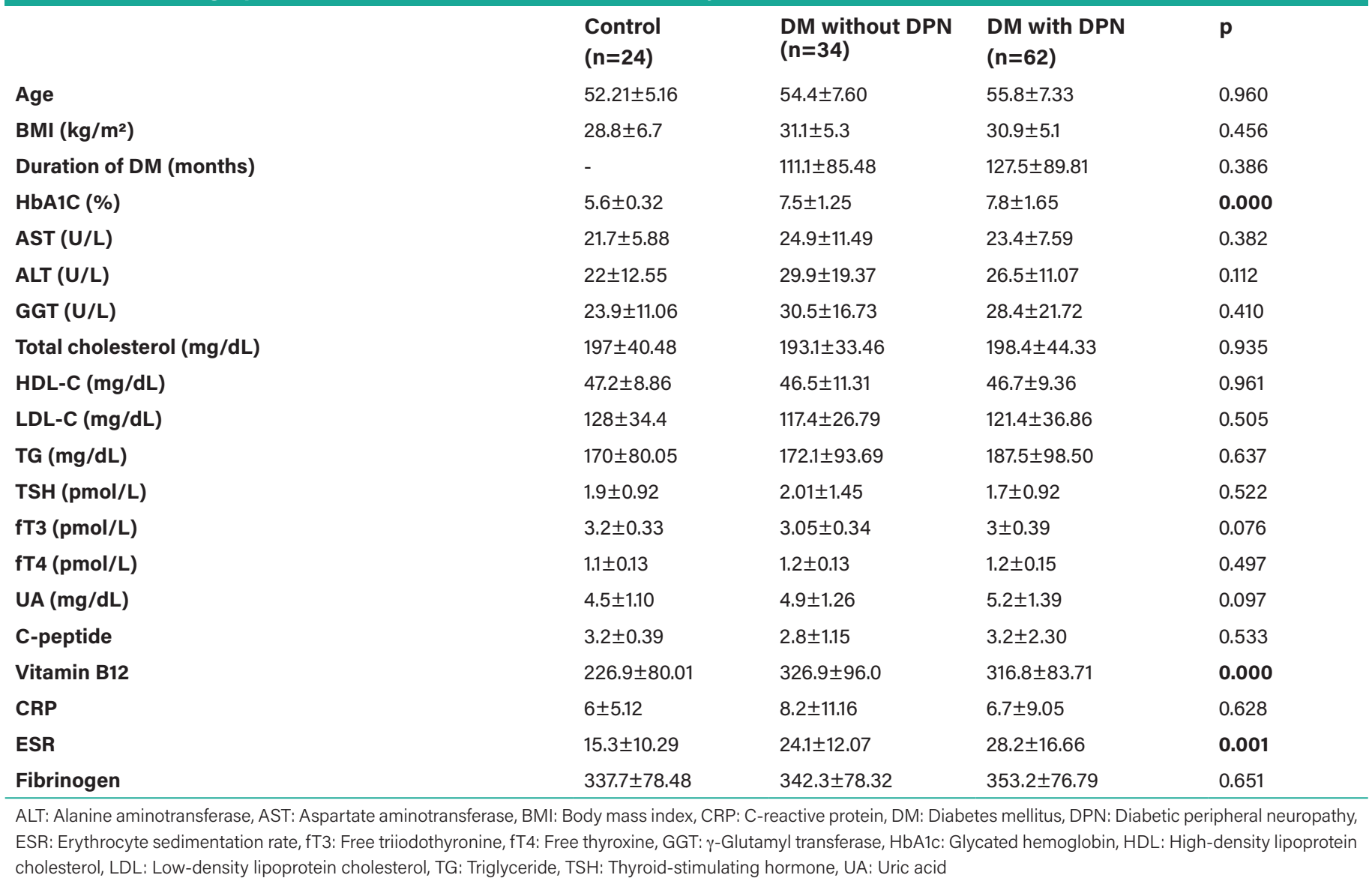


A comparison of DPN patients with neuropathic pain (LANSS $\geq 12$ ) and without neuropathic pain (LANSS <12) showed that CRP and LDL-C levels were statistically significantly higher in the group with neuropathic pain ( $\mathrm{p}=0.008$ and $\mathrm{p}=0.030$, respectively) (Table 2 ).

\section{Discussion}

In our research, LDL-C and CRP levels were higher in painful DPN patients than in those without pain. UA, GGT, CRP, ESR, and fibrinogen levels were not different in DM patients with and without DPN and these indicators were not considered to be associated with the development of DPN.

The most common clinical form of DPN is chronic distal symmetric polyneuropathy, and patients with diabetes may develop asymmetric, focal, or multifocal neuropathies.

Table2. Laboratory examinations of diabetic polyneuropathy patients with or without pain

\begin{tabular}{llll} 
& $\begin{array}{l}\text { LANSS }<12 \\
(\mathbf{n}=\mathbf{8 6})\end{array}$ & $\begin{array}{l}\text { LANSS } \geq 12 \\
(\mathbf{n}=10)\end{array}$ & $\mathbf{p}$ \\
\hline Age & $55.2 \pm 7.32$ & $56.4 \pm 8.55$ & 0.690 \\
BMI & $30.7 \pm 4.96$ & $31.6 \pm 6.32$ & 0.705 \\
Duration of DM & $122.6 \pm 85.94$ & $114 \pm 110.88$ & 0.815 \\
(months) & & & \\
HbA1C (\%) & $7.7 \pm 1.50$ & $7.8 \pm 1.73$ & 0.826 \\
AST (U/L) & $24.0 \pm 9.50$ & $23.3 \pm 5.18$ & 0.704 \\
ALT (U/L) & $27.8 \pm 15.13$ & $26.5 \pm 8.50$ & 0.666 \\
GGT (U/L) & $29.7 \pm 20.81$ & $23.9 \pm 10.37$ & 0.156 \\
Total cholesterol & $197 \pm 39.93$ & $174.1 \pm 42.89$ & 0.135 \\
(mg/dL) & & & \\
HDL-C (mg/dL) & $47.2 \pm 9.95$ & $41.7 \pm 9.85$ & 0.122 \\
LDL-C (mg/dL) & $121.9 \pm 34.2$ & $103.5 \pm 21.38$ & $\mathbf{0 . 0 3 0}$ \\
TG (mg/dL) & $183.5 \pm 100.02$ & $169.6 \pm 61.97$ & 0.543 \\
TSH (pmol/L) & $1.8 \pm 1.14$ & $2.1 \pm 1.10$ & 0.386 \\
fT3 (pmol/L) & $3.01 \pm 0.38$ & $3.08 \pm 0.28$ & 0.494 \\
fT4 (pmol/L) & $1.22 \pm 0.14$ & $1.1 \pm 0.13$ & 0.409 \\
UA (mg/dL) & $5.1 \pm 1.31$ & $5.4 \pm 1.71$ & 0.515 \\
C-Peptide & $3.1 \pm 2.07$ & $2.5 \pm 0.84$ & 0.112 \\
Vitamin B12 & $320.4 \pm 85.61$ & $320 \pm 110.95$ & 0.990 \\
CRP & $7.5 \pm 10.30$ & $4.1 \pm 1.95$ & $\mathbf{0 . 0 0 8}$ \\
ESR & $26.9 \pm 15.18$ & $25.2 \pm 16.62$ & 0.751 \\
Fibrinogen & $348.5 \pm 78.05$ & $355.8 \pm 71.81$ & 0.771 \\
\hline LANSS: & & \\
\hline
\end{tabular}

LANSS: Leeds assessment of neuropathic symptoms and signs scale, ALT: Alanine aminotransferase, AST: Aspartate aminotransferase, BMI: Body mass index, CRP: C-reactive protein, ESR: Erythrocyte sedimentation rate, fT3: Free triiodothyronine, fT4: Free thyroxine, GGT: $\gamma$-glutamyl transferase, HbA1c: Glycated hemoglobin, HDL: High-density lipoprotein cholesterol, LDL: Low-density lipoprotein cholesterol, TG: Triglyceride, TSH: Thyroid-stimulating hormone, UA: Uric acid
This clinical diversity in DPN is possibly related to different underlying pathophysiological mechanisms.

Although the pathogenesis has not been fully elucidated, the development of DPN has been attributed to vascular dysfunction caused by metabolic changes associated with chronic hyperglycemia. Chronic hyperglycemia leads to changes including shunting into the polyol pathway, reduced nerve and Schwann cell myo-inositol levels, oxidative and nitrative stress, lack of neurotrophic factors, and their uptake in microvessels and neurons (2). The complex interaction of these factors results in endothelial dysfunction, reduced nerve perfusion, and endoneurial hypoxia (1-3).

DPN is a microvascular complication of DM, and the pathogenesis of DPN development includes ischemia and vascular processes along with metabolic events associated with hyperglycemia. Like DM, DPN has been reported to be associated with cerebral microvascular damage (13). Here, the higher CRP levels in painful DPN patients suggest that inflammatory mechanisms also play a role in this process.

Early detection of DPN is crucial to identify and control risk factors and to prevent and slow down the DPN process.

UA, GGT, CRP, ESR, and fibrinogen are possible markers of the atherosclerotic process. Based on the assumption that these markers may be related to the vascular processes involved in the pathogenesis of DPN and may be considered as indicators of DPN, the relationship between UA, GGT, CRP, ESR, and fibrinogen, and DPN has been investigated in various studies $(2,6,14-23)$. However, the results of these studies are conflicting.

At normal levels, UA is known to clear toxic reactants and provide protection opposed to oxidative stress. However, UA is seen to play a prooxidant part when increased by a third or more than normal levels (6). Endothelial dysfunction, platelet adhesion, and aggregation have been associated with hyperuricemia (14). The role of UA in DM patients has been investigated in various studies (14-17). UA levels are high in DM patients and it has been suggested that the cause of this elevation may be increased production or reduced excretion of UA. However, the pathophysiological mechanism has not been fully revealed. On the other hand, studies indicate that UA is reduced in DM, for which the reason has been indicated as increased UA clearance in $\mathrm{DM}$, and again, the mechanism has not yet been clarified (15).

The number of studies investigating the relationship between DPN development and UA levels is limited. It 
has been reported that UA levels are higher in patients with type $2 \mathrm{DM}$ with neuropathy than patients without neuropathy. Hyperuricemia has been reported to be related to hyperglycemia, dyslipidemia, and metabolic syndrome, all of which are related to the development of DPN. UA can cause endothelial dysfunction, which may lead to the DPN. Type 2 DM patients with peripheral neuropathy have markedly increased serum UA levels and hyperuricemia is associated with a rising risk of peripheral neuropathy (15-17). In our study, there was not statistically difference of the two groups despite higher UA levels.

The correlation between UA levels and DPN was previously related to metabolic syndrome (7). In this study, the reason for no significant relationship between UA and DPN may be the fact that patients with metabolic syndrome due to BMI or other factors (the absence of certain microalbuminuria) were indirectly excluded, and that DM patients with characteristics similar to the controls were included in the study. Although the UA's role in the development of vascular adversities of diabetes has been known, its role in the development of DPN remains unclear.

CRP, a sensitive biomarker of subclinical systemic inflammation, is related to the development and progression of DPN (18). CRP levels have been shown to be related to the development of DPN $(15,18)$.

There are enough studies in the literature investigating the role of dyslipidemia in the development of neuropathy and other microvascular complications in DM patients. Besides, different studies have shown that lipid-lowering treatment reduces the development of these complications. It has been experimentally proven that increased TG and LDL-C levels damage neurons through oxidative stress (19). Increased TG and LDL-C levels and decreased HDL-C levels constitute a risk for the development of DPN in diabetic patients. One study revealed that increased TG levels correlated with the development of DPN $(20,21)$. In our study, although TG levels were found to be higher in DPN patients, no statistically significant difference was found.

There is also evidence of direct proinflammatory effects of CRP by triggering the synthesis of local adhesion molecules, reducing endothelial nitric oxide activity, altering LDL cholesterol uptake by macrophages, and inducing intravascular thrombosis (22).

In a previous study, it was shown that high CRP levels might be evidence of subclinical inflammation in peripheral DPN
(20). In one study, it was found that increased biochemical markers included fibrinogen and CRP, reflecting inflammation and endothelial dysfunction in peripheral DPN (23).

In another study, higher levels of CRP were reported in painful DPN patients than those without pain, it was suggested that inflammation and endothelial dysfunction might play a role in the occurrence of painful neuropathy (23).

Inflammatory mediators, particularly cytokines, have been suggested a decisive role in the pathogenesis of neuropathic pain. In our study, a significant difference was not found in patients with and without DPN in terms of CRP levels, whereas patients with painful DPN had higher levels of CRP than the patients with painless DPN. In the literature, in neuropathic pain with sciatica patients, it has been reported that neuropathic pain is associated with high CRP levels (18).

Inflammation has been recommended to be a considerable risk factor in the formation of DPN as well as type $2 \mathrm{DM}$ (1-3). However, there are limited data on the relationship between DPN, and vascular diseases and inflammation (13).

The higher level of CRP in painful DPN may be due to the inflammatory response created by this microvascular ischemic injury.

\section{Conclusion}

Although levels of UA, CRP, GGT, fibrinogen, and ESR were reported to be elevated in DPN patients, these biochemical parameters were not detected as markers for DPN in our study.

In this study, a significant relationship was found between DPN patients with neuropathic pain and increased CRP levels.

Increased CRP levels in DPN patients with neuropathic pain may reflect the inflammatory mechanisms involved in the pathogenesis of pain associated with DPN. The elevation of serum CRP levels in DPN patients with neuropathic pain is a remarkable finding. This condition indicates that CRP in DPN patients is closely associated with neuropathic pain.

Increased CRP, regardless of any other factor, in DPN patients with neuropathic pain indicates that this variable may be helpful to appropriately select patients for neuropathic treatment medicines. 
Even, in DM patients who are considered normal by examination or ENMG, CRP levels can be used to help clinically "indeterminate" neuropathic pain patients.

\section{Ethics}

Ethics Committee Approval: This study was approved by the Ethics Board of the Institutional Review Committee of the University of Health Sciences Turkey, Dışkapı Yıldırım Beyazit Training and Research Hospital (2014-15/9).

Informed Consent: Informed consent was obtained from all individual participants included in the study.

Peer-review: Externally peer-reviewed.

\section{Authorship Contributions}

Concept: M.P.A., S.F., H.G., Design: M.P.A., S.F., H.G., Data Collection or Processing: M.P.A., S.F., Analysis or Interpretation: M.P.A., H.G., S.S.Ç., Literature Search: M.P.A., S.S.Ç., Writing: M.P.A., S.S.Ç.

Conflict of Interest: No conflict of interest was declared by the authors.

Financial Disclosure: The authors declared that this study received no financial support.

\section{References}

1. Tesfaye S, Selvarajah D. Advances in the epidemiology, pathogenesis and management of diabetic peripheral neuropathy. Diabetes Metab Res Rev 2012;28(Suppl 1):8-14.

2. Stevens MJ, Feldman EL, Greene DA. The aetiology of diabetic neuropathy: the combined roles of metabolic and vascular defects. Diabet Med 1995;12(7):566-579.

3. Malik RA, Tesfaye S, Newrick PG, Walker D, Rajbhandari SM, Siddique I, et al. Sural nerve pathology in diabetic patients with minimal but progressive neuropathy. Diabetologia 2005;48(3):578585.

4. Wannamethee G, Ebrahim S, Shaper AG. Gammaglutamyltransferase: determinants and association with mortality from ischemic heart disease and all causes. Am J Epidemiol 1995;142(7):699-708.

5. Backes JM, Howard PA, Moriarty PM. Role of C-reactive protein in cardiovascular disease. Ann Pharmacother 2004;38(1):110-118.

6. Demir M, Bulunmaz M, Müderrisoğlu C, Kose S, Erdem S, Polat H. Role of uric acid in determining cardiovascular risk. İstanbul Med J 2014;15:203-208.

7. Habib SS, A Al Masri A. Relationship of high sensitivity C-reactive protein with presence and severity of coronary artery disease. Pak J Med Sci 2013;29(6):1425-1429.

8. Ates U, Bahadir K, Ergun E, Gollu G, Durmaz M, Gunay F, et al. Determination of Pentraxin 3 levels in diagnosis of Appendicitis in children. Pediatr Int 2020;62(5):624-628.
9. Cengiz AB, Gümüşlü BC, Kayabaşı S, Tansuker HD, Öğreden Ş, Oktay MF. C-reactive protein to albumin ratio as a prognostic predictor in larynx cancer. Bagcilar Med Bull 2020;5(4):179-184.

10. Özyüncü N, Güleç HS, Özcan ÖU, Göksülük H, Gerede Uludağ DM, Erol Ç. Comparison of the Effects of Bare Metal Stents and Drug Eluting Stents on C-Reactive Protein Levels. J Ankara Univ Fac Med 2020;73(3):208-215.

11. Cook NS, Ubben D. Fibrinogen as a major risk factor in cardiovascular disease. Trends Pharmacol Sci 1990;11(11):444-451.

12. Dyck PJ, Albers JW, Andersen H, Arezzo JC, Biessels GJ, Bril V, et al; Toronto Expert Panel on Diabetic Neuropathy. Diabetic polyneuropathies: update on research definition, diagnostic criteria and estimation of severity. Diabetes Metab Res Rev 2011;27(7):620-628.

13. Ferik S, Güven H, Ateş MP, Conkbayır I, Çomoğlu S, Güven B. Diabetic polyneuropathy, deep white matter lesions, and carotid atherosclerosis: is there any association? Neurol Sci 2018;39(1):103110 .

14. Yu S, Chen Y, Hou X, Xu D, Che K, Li C, et al. Serum uric acid levels and diabetic peripheral neuropathy in type 2 diabetes: a systematic review and meta-analysis. Mol Neurobiol 2016;53(2):1045-1051.

15. Pafili K, Katsiki N, Mikhailidis DP, Papanas N. Serum uric acid as a predictor of vascular complications in diabetes: an additional case for neuropathy. Acta Diabetol 2014;51(5):893-894.

16. Kiani J, Habibi Z, Tajziehchi A, Moghimbeigi A, Dehghan A, Azizkhani H. Association between serum uric acid level and diabetic peripheral neuropathy (A case-control study) Caspian J Intern Med 2014;5(1):17-21.

17. Papanas N, Katsiki N, Papatheodorou K, Demetriou M, Papazoglou $\mathrm{D}$, Gioka T, et al. Peripheral neuropathy is associated with increased serum levels of uric acid in type 2 diabetes mellitus. Angiology 2011;6(4):291-295.

18. Uher T, Bob P. Neuropathic pain, depressive symptoms, and C-reactive protein in sciatica patients. Int J Neurosci 2013;123(3):204-208.

19. Ridker PM, Danielson E, Fonseca FA, Genest J, Gotto AM Jr, Kastelein JJ, et al; JUPITER Trial Study Group. Reduction in C-reactive protein and LDL cholesterol and cardiovascular event rates after initiation of rosuvastatin: A prospective study of the JUPITER trial. Lancet 2009;373(9670):1175-1182.

20. Ge S, Xie J, Zheng L, Yang L, Zhu H, Cheng X, et al. Associations of serum anti-ganglioside antibodies and inflammatory markers in diabetic peripheral neuropathy. Diabetes Res Clin Pract 2016;115:68-75.

21. Wiggin TD, Sullivan KA, Pop-Busui R, Amato A, Sima AA, Feldman EL. Elevated triglycerides correlate with progression of diabetic neuropathy. Diabetes 2009;58(7):1634-1640.

22. Ridker PM, Libby P. Risk factors for atherothrombotic disease. In: Bonow RO, Mann DL, Zipes DP, Libby P (editors). Braunwald's Heart Disease. Saunders Philadelphia: Elsevier, 2014;39:1003-1026.

23. Doupis J, Lyons TE, Wu S, Gnardellis C, Dinh T, Veves A. Microvascular reactivity and inflammatory cytokines in painful and painless peripheral diabetic neuropathy. J Clin Endocrinol Metab 2009;94(6):2157-2163. 